\title{
超音波流速分布計を用いた環境流動場計測*
}

\author{
横山 馨*1, 小嶋 慎 哉*1, 大 窪 智 行*2 \\ 田坂 裕司*2, 武田 靖*2,-吉田 静 男*2
}

\section{Environmental Flow Measurement Using Ultrasonic Velocity Profiler}

\author{
Kaoru YOKOYAMA, Shinya KOJIMA, Tomoyuki OHKUBO, \\ Yuji TASAKA*3, Yasushi TAKEDA and Shizuo YOSHIDA \\ ${ }^{* 3}$ Division of Energy and Environmental Systems, Graduate School of Engineering, Hokkaido University, \\ N 13 W 8 Kita-ku, Sapporo-shi, Hokkaido, 060-8628 Japan
}

\begin{abstract}
Ultrasonic Velocity Profiler (UVP) was applied to an environmental flow attempting an efficient measurement of river flow. In a lab-scale open channel, a velocity distribution in a channel cross section was obtained and a flow rate was estimated. We confirmed that the flow rate in an open channel can be measured with an accuracy as high as $5 \%$. It was also established to detect the bottom position from a single velocity distribution, which might give us information about the geometry and condition of the bottom surface of the channel. We practiced the method in a small river, and showed that it might give us flow rate of the river with higher accuracy than conventional methods.
\end{abstract}

Key Words : Environmental Flow Measurements, Open Channel, Velocity Distribution, Flow Rate, Bottom Surface, Ultrasonic Velocity Profiler

\section{1. 粕}

集中豪雨による河川の氾濫など, 科学技術の発達し た現在でさえ，水害の問題は深刻である．川の流れは 河床を侵食し, 土砂を輸送, 堆積させることによって 新たな地形を形成する. それにより流れの様子も時々 刻々と変化しており, 流れに適した堤防や橋标を設計 するためには, 変化した河床の形状と流れの様子を正 確に把握する必要がある. また近年, 諫早湾の水門設 置によるのり養殖の被害のように, 河川や海岸に建設 された人工構造物がもたらす流れの大規模な変化は, 我々の生活に大きな影響を及ぼし，そこから回復する には長い年月が必要となるであろう。しかしながら， そのような流れの変化についての調査および改善には, 広範囲の流れを計測する必要があり, 対策が遅れてい る一つの原因となっている. これらの計測では, 計測 対象が広範囲にわたり, また流れも複雑であるため, 河川などの底面形状も含めた環境流動場全体を, 効率 的に計測することが必要である. しかし, 電磁流速計 やプロペラ流速計など, 現行の点計測式流速計により 流動場を計測するには, 膨大な時間が必要である. そ

\footnotetext{
* 原稿受付 2005 年 9 月 12 日.

*1 北海道大学大学院工学研究科(函 060-8628 札幌市北区北 13 条西 8 ).

*2 正員, 北海道大学大学院工学研究科.

E-mail : tasaka@eng.hokudai.ac.jp
}

こで近年，画像計測や音波などを用いて広範囲の流動 場を効率的に計測する手法が研究, 提案されている ${ }^{(1)}$ 〜 (4). しかしながら現在のところ, 実用に足る汎用的 な計測法は確立されていない．また流速計測とは別途 行われる，断面形状の把握に必要な，ポールや音響測 深器などを用いた水深計測も, 流動場計測の高効率化 を妨げる要因となっている.

本研究ではこれらの課題を大幅に解消できる計測手 法として, 超音波流速分布計 ${ }^{(5)}$ (Ultrasonic Velocity Profiler，以下 UVP) に着目した. UVP では超音波ビ 一ムの伝播方向に沿った瞬時流速分布計測が可能であ り，流動場を効率的に把握することができる．また， 高速アルゴリズムにより後処理を施すことなく瞬時速 度分布が得られるため, 流速分布のリアルタイムでの 観測が可能である. さらに, LDA などの光学的な手法 では計測できない，泥などで蜀った流れの計測にも適 用できる.このような特徵から，これを用いた高精度 管内流量計が研究・開発され(6)，現在製品化が進めら れている(7).これに対し環境流動場計測では，これま で実験室モデルを用いた基礎研究はいくつか行われて いるものの ${ }^{(8)(9)}$ ，実際の環境流動場で使用することを 想定した研究はごく僅かである(10).

流動場の断面形状計測については, UVP の特徵 である流速分布計測に着目すると，底面では理論上流 
速がゼロとなることから, 流速分布データの処理のみ により底面を自動検出することができる．したがって， これを用いることにより流速分布と水深の同時計測が 可能となり, 流動場計測の更なる効率化につながると 予想される.

本研究では, UVP の環境流動場計測一の応用を目的 とし，そのための基磷的研究を行った. 実験室開水路 において, UVP によって計測された速度分布から算出 した流量の確度を検証した. 現行で使用されている, ポールなどを用いた底面検出法に代わるものとして， 計測した流速分布を利用した効率的な底面検出方法に ついて検討した．また，実験室水路での結果を基に実 際の河川において計測を行い，提案した底面検出法の 実用性および計測の問題点を検討した。

\section{2. 主な記号}

$Q \quad$ : UVPにより得られた時間平均流量 $1 / \mathrm{s}$

$Q_{r} \quad$ ：UVP による円管内流量計測または四角 堰によって得られた基準流量 $1 / \mathrm{s}$

$t \quad:$ 計測開始からの時間 $\mathrm{s}$

$u$ : 流速の $x$ 方向成分 $\mathrm{mm} / \mathrm{s}$

$\bar{u}: u$ の時間平均 $\mathrm{mm} / \mathrm{s}$

$x, y, z: x$ 軸, $y$ 軸, および $z$ 軸の座標 $\mathrm{mm}$

$\Delta y: y$ 軸方向の計測間隔 $\mathrm{mm}$

$\Delta t \quad:$ サンプリング時間間隔 $\mathrm{s}$

$\Delta u$ : 速度分解能 $\mathrm{mm} / \mathrm{s}$

$\Delta z:: z$ 軸方向の計測点間距離 $\mathrm{mm}$

$\theta \quad:$ 超音波トランスデューサの, $z$ 軸に対 する設置角度 deg

\section{UVPによる開水路計測と流量算出法}

図 1 にUVP の原理を示した概念図を示す. 図 1 (a)のように，先端を水中に挿入して固定した超音波 トランスデューサ (US transducer) から, 基本周波数 $f_{0}$ の超音波バーストを発射する. 水中に分散してい る散乱粒子からの反射波を, 同じトランスデューサ によって受信する（図1(b)）。このとき反射波に 加わる, 粒子の速度に依存したドップラーシフト周 波数を基に, 次式により流速の $\xi$ 方向成分 $u_{\xi}$ 算出 する.

$$
u_{\xi}=\frac{c f_{d}}{2 f_{0}}
$$

ここで, $c$ は水の音速,$f_{d}$ はドップラーシフト周 波数である.また粒子の位置は超音波の飛行時間 から決定し，

$$
\xi=\frac{c T}{2}
$$

となる. なお， $T$ は超音波の飛行時間である.この
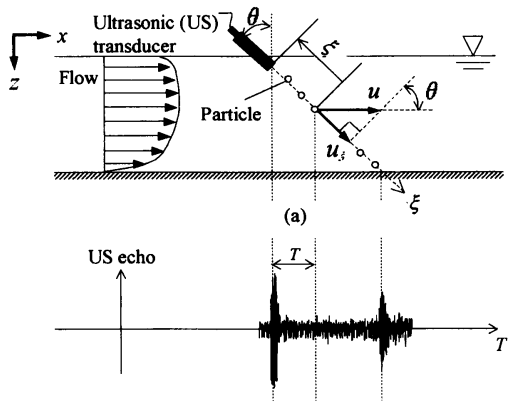

(b)

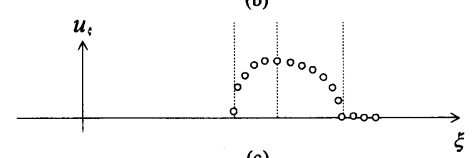

(c)

Fig.1 Schematic of process of velocity profile measurement using UVP at an open channel

処理を超音波の伝播線上の各位置について行うこと により，図 1 (c)に示すようにその線上の瞬時流速分 布を得ることができる. なお, 計測するのは $u_{\xi}$ であ るため, 計測線と直交するような流れは流速がゼロ となる．したがって開水路計測では，主流方向の流 速 $u$ を計測するために, 鉛直軸に対して角度 $\theta$ を付 けてトランスデューサを設置する， $u$ は，流れが $x$ 方向にしか流速を持たない 1 次元流であると仮定す ると, 図 1 に示すように $u_{\xi}$ と $\theta$ から $u=u_{\xi} / \sin \theta$ として求まる.

流速分布計測は, Met-Flow 社製 UVP monitor model - Duo を用いて行った. 連続して計測した 1024 枚の瞬時速度分布を時間平均し, 平均速度分布 を求めた.この計測を流路スパン方向に一定間隔 $\Delta y$ で行い，断面流速分布を得た．またそれを用い て開水路流量を算出した. 鉛直方向に $z$ 軸, スパン 方向に $y$ 軸をとると, $y-z$ 断面における全流量 $Q$ は 平均流速分布 $\bar{u}(y, z)$ を用いて次式によって与えj れる。

$$
\begin{aligned}
& Q=\iint \bar{u}(y, z) d y d z \\
& \cong \sum_{i=0}^{k}\left(\sum_{j=0}^{m} \bar{u}_{i, j} \times \Delta y \times \Delta z\right)
\end{aligned}
$$

ここでサフィックス $\mathrm{i}, \mathrm{j}$ はそれぞれ $y, z$ 方向の計 測点を表している. また $\Delta z$ は $z$ 方向の計測点間距 離であり, 計測線方向の計測点間距離を $\Delta \xi$ とする と, $\Delta z=\Delta \xi \cos \theta$ のように求められる. $\Delta \xi$, 速度分

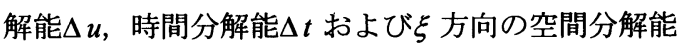
は, 通常測定対象となる流れの範囲, 流速および液 
Table 1 Specifications of measurement condition

\begin{tabular}{|c|c|c|}
\cline { 2 - 3 } \multicolumn{1}{c|}{} & Open channel & River \\
\hline$\Delta u$ & $12.8 \mathrm{~mm} / \mathrm{s}$ & $30.6 \mathrm{~mm} / \mathrm{s}$ \\
\hline$\Delta \xi$ & $1.85 \mathrm{~mm}$ & $1.48 \mathrm{~mm}$ \\
\hline$\Delta y$ & $10 \mathrm{~mm}$ & $100 \mathrm{~mm}$ \\
\hline$\Delta t$ & $0.12 \mathrm{sec}$ & $0.13 \mathrm{sec}$ \\
\hline
\end{tabular}

体の音速，使用する超音波の周波数などによって 異なる．本研究では超音波トランスデューサの基 本周波数を $2 \mathrm{MHz}$ とし，また一つの速度分布に含 まれる計測区間の数を 128 区間に固定し， $\Delta \xi$ は 空間分解能と等しい值に設定した. 開水路および 小川を計測した際の各パラメータを表 1 に示す.

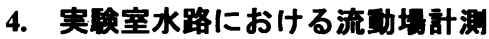

4・1 実医装量および実験方法 流動場計測に用い た実験室水路の概略図を図 2 (a)に示す. 装置は開水路 と円管，ポンプから構成されている. 円管部に設置し たポンプによって, ループに水を循環させた．流量は, インバータ制御器を用いてポンプの出力を制御し, 約 $1 \sim 5 \mathrm{l} / \mathrm{s}$ の範用で変化させた. 開水路は幅 $300 \mathrm{~mm}$, 高さ $300 \mathrm{~mm}$ ，全長 $3000 \mathrm{~mm}$ のアクリル製である．図 2 (b)のように，流入口の壁面の角に原点をとり，流れ方 向に $x$ 軸，流路断面の水平方向に $y$ 軸，鈆直下方向に $z$ 軸をとる. 開水路入り口は $y=150 \mathrm{~mm}$, 底面からの高 さ $60 \mathrm{~mm}$ の位置を中心とした直径 $65 \mathrm{~mm}$ の円形である. 円管部は内径 $50 \mathrm{~mm}$ ，全長 $3000 \mathrm{~mm}$ である. 開水路 計測部は $x=1900 \mathrm{~mm}$ に設けた. トランスデューサは, 先端付近での流れの乱れを抑えるために上流側入向け， $\theta=8 \mathrm{deg}$ として先端 $10 \mathrm{~mm}$ を水中に挿入し固定した

(図 2(c)）. 本研究では, 構築したシステムの, 実際 の環境流動場での使用を前提としているため, 流速計 測のためのトレーサ粒子を意図的に混入することなく， タンクと開水路で自然混入される微小気泡を超音波反 射体として用いた， $y-z$ 断面流速分布は，流路中心軸 に対して左右対称であると考え，y=10 $\mathrm{mm}$ から 150 $\mathrm{mm}$ までの流路断面半分について $10 \mathrm{~mm}$ ごとに流速分 布計測を行った．またポンプ手前の円管部において, 東京電力（株）製 Ud-Flow を使用した流量計測を行い， UVP による開水路流量計測との比較のための基淮流量 $Q ，$ とした. なお Ud-Flow は， 円管内流量計測に特化 した UVP システムであり, 複数の流量試験場での検定 で誤差 $1 \%$ 以下という高確度を持つことが確認されて いる(6).

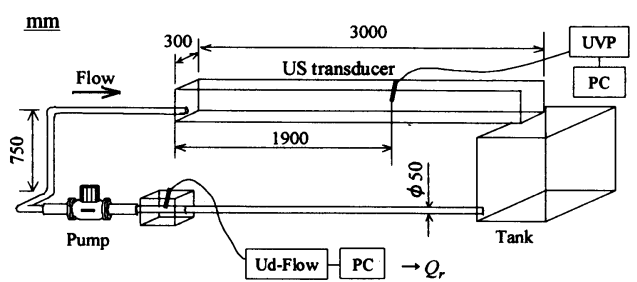

(a)

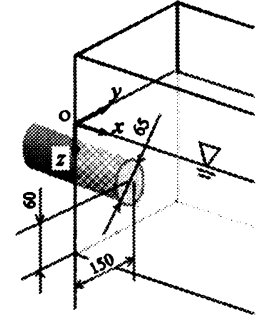

(b)

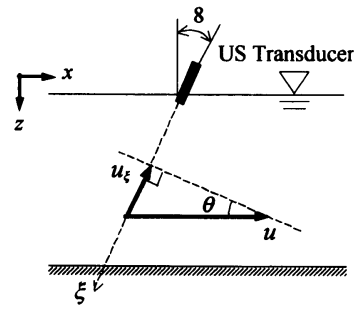

(c)
Fig. 2 (a) Schematic of open channel system, (b) enlarged inflow part and (c) configuration of US transducer

$4 \cdot 2$ 流速分布計測銡果 図 3 は, $Q_{r}=2.231 / \mathrm{s}$ の流 れについて, $y=150 \mathrm{~mm}$ において計測した鋁直方 向流速分布であり, 図の横軸は $z$, 縦軸は時間平均 流速 $\bar{u}$ である. エラーバーは， $u$ の標準偏差 $\sigma$ を 示している. $z=170 \mathrm{~mm}$ 付近の, $\bar{u}$ と $\sigma$ がともに小 さくなっている部分が開水路の底面であり, 図中に 破線で示すスケールによって計測した底面位置とほ ぼ一致する．底面より先での流速は超音波が底面で 反射し, 反射した先での流速を得たものである. 速 度分布の形状に注目すると, $z=80 \mathrm{~mm}$ 付近から速度 が大きくなっていることが分かる.これは開水路上 流に設置された円管からの噴出しの影響であり， $\bar{u}$ が最大値を取る $z=120 \mathrm{~mm}$ は噴出し口の中心高さに ほぼ一致する．またトランスデューサ先端付近では, 流体がトランスデューサの前面に沿うように流れる ため $u_{\xi}$ が小さくなる. その結果, この領域の数点で

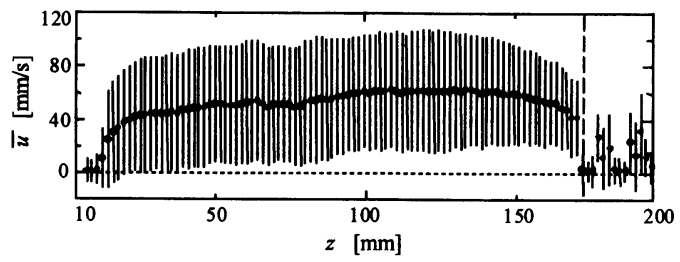

Fig. 3 Temporally averaged velocity profile measured by UVP 


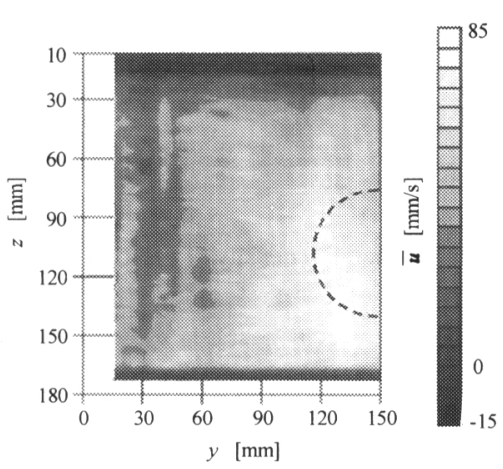

Fig. 4 Velocity distribution at a $y-z$ cross section in open channel

は現実と異なり， $\bar{u}$ はゼロに近い值として計測され ている.

同条件の下に $y$ 方向の各位置で計測を行い，得られた 平均流速分布を基に平均流速の $y-z$ 断面分布を作成した。 図 4 にその結果を示す. 図の横軸と縦軸はそれぞれ $y$ と $z$ であり, グレースケールは各位置における $\bar{u}$ の大き を示している，底面は，スケールによって計測した距 離を基に決定した． 断面流速分布から， $\bar{u}$ が最大值を 取る領域は $y=120 \sim 150 \mathrm{~mm}, z=100 \sim 160 \mathrm{~mm}$ 付 近であり，図中に破線で示した噴出し口からの流れの 影響が明瞭に現れている.

4.3 流量補正方法 図4に示した平均流速の $y-z$ 断面 分布と(3)式を用いて流量を算出する，算出にあたり， 鉛直方向流速分布に対して 2 種類の補正を行った. 1 つ は超音波反射体の不足による，計測点の欠落に対する 補正である，UVP では，計測点上に反射体が存在しな い場合，速度を求める信号処理の過程で誤った流速が 算出される，本実験では，自然混入される気泡を反射 体として用いているため，そのような反射体の不足に よる誤差が生じやすい. そこで 1024 枚の瞬時流速分布 から, 各位置の流速についてショーブネの判断基準 (11) を用いてデータの亲却を行った. $Q_{r}=2.23 \mathrm{l} / \mathrm{s}, \quad y=$ $150 \mathrm{~mm}$ での流速分布についてこの方法を用いた結 果, 約 $15 \%$ のデータが棄却された. 図 5 にこの場合の データ棄却前後の平均流速と標準偏差を示す.データ 棄却後, 平均流速は約 $3 \%$ 上昇し，標準偏差は大幅に減 少している，これは反射体が存在しない場合，小さな 流速值が出力されるためである. 同様に各計測データ について新たな平均流速と標準偏差を求め, 流量算出 に用いた。

もう一方の補正は，トランスデューサ先端部分の領 域の補正である. トランスデューサを水中に挿人した 領域では流速が計測されず，また前節で述べた理由か

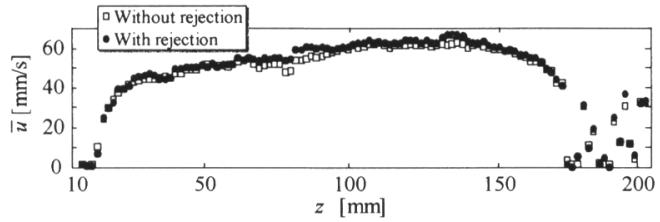

(a)

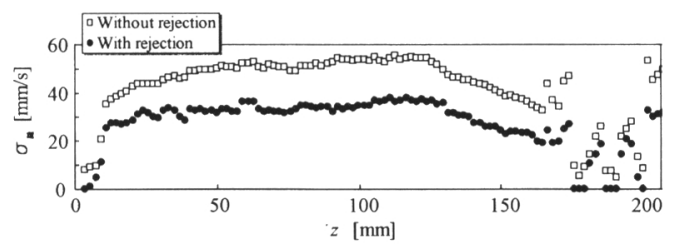

(b)

Fig. 5 (a) Temporally averaged velocity profile and (b) standard deviation profile with and without data rejection

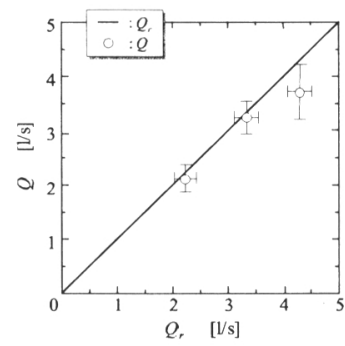

Fig. 6 Flow rate in open channel measured by UVP

らトランスデューサ近傍では実際の流速よりも小さな 值として計測されるため, これらの部分を合わせて補 正する必要がある。ここでは，流速が落ち込む直前の 值を用いて補正を行った，各平均流速分布について， トランスデューサ先端付近の 10 点を対象とし, 流速の 差分を求めてその最大值を取る位置を, トランスデュ 一サの影響を受けて速度が落ち込む位置とみなした。 その後方点での流速を, その点から水面までの領域の 代表值とした.

上記の 2 種類の補正を行って算出した開水路流量を 図 6 に示す. グラフの横軸は基準流量 $Q$ n 縦軸は UVP を用いて測定した開水路の平均流量 $Q$ である. 横軸方 向のエラーバーは $Q_{r}$ の標準偏差を, 縦軸方向のエラー バーは各計測点での流速の標準偏差から見積もつた $Q$ の標準偏差を示している. $Q_{r}=2.23$ および $3.34 \mathrm{l} / \mathrm{s}$ で は，基準流量との誤差は約 $4 \%$ と高確度の流量計測が実 現されている. これに対し $Q_{r}=4.30 \mathrm{l} / \mathrm{s}$ では, 誤差が 約 $14 \%$ と他の 2 例と比較して大きくなっている. これ は, 円管部からの噴出しの影響が計測位置でも強く残 っており，本研究が想定している 1 次元流から大きく 
離れているためである. したがって，人為的な流れの 噴出しなどのない， 1 次元流の仮定が十分成り立つ流れ であれば，この手法を用いて高確度の開水路流動場計 測が実現できる.

\section{5. 開水路底面検出}

5-1 底面検出方法 図 3 に示したように, UVP により計測された速度分布では，底面付近で流速がほ ぼゼロとなり標準偏差も非常に小さい值となっている ことから，流速のばらつきも小さいことがわかる．し たがって，底面に相当する位置では流速がゼロと計測 される割合が大きくなることが予想される.ここでい う流速がゼロとは, $u=0$ を挟んだ速度分解能 $\Delta u$ 分の範 囲内の值，すなわち $-\Delta u / 2<u<\Delta u / 2$ となるような 流速である. 図 3 と同じ条件で計測した 1024 枚の速度 分布において，流速ゼロと計測された確率の分布を図 7 に示す．縦軸は各計測点で流速がゼロと計測される確 率 $P d_{0}$ である. ここで $P d_{0}=0.5$ という值は，ある測 定点で 1024 回の測定中 512 回流速がゼロと計測された ことを意味している. 図から分かるように, $P d_{0}$ は底面 付近で急激に大きくなっており，何らかのしきい值を 設けてこの位置を決定することで, 底面検出が可能で あると考えられる．なお，データ棄却によって底面近 傍での流速ゼロのデータが棄却される可能性を防ぐた め, この底面検出はデー夕菓却処理の前に行った.

$5 \cdot 2$ 底面検出方法の検証 この底面検出方法を 検証するために，開水路において以下の 3 種類の底面 状態に関して実験を行った. 第一は，特に何も施さな いフラットな底面，第二に底面に凹凸がある場合とし て，その形状が既知であるゴルフボールを底面に敷き 詰めた場合，そして第三は，表面状態が複雑な人工芝 の底面である. ゴルフボールは直径約 $42.5 \mathrm{~mm}$ であり $y$ 方向に 7 個設置した. $x$ 方向には, 十分な助走距離を 取るために計測部より約 $1500 \mathrm{~mm}$ 上流から密接して敷 き詰めた. 人工芝は $30 \times 30 \mathrm{~mm}$ ，平均厚さ $20 \mathrm{~mm}$ の正方形であり，これを計測部底面に設置した. 流量 は $Q_{r}=2.23 \mathrm{l} / \mathrm{s}$ である. $y$ 方向計測位置は, 底面がフラ ットな場合と人工芝の場合は $y=10 \mathrm{~mm}$ から $10 \mathrm{~mm}$ 間 隔で 15 個所とした. また，底面の凹凸が大きいゴルフ ボールの場合では超音波ビームの中心がボールの頂部 にあたるようにトランスデューサを設置し，y=15 mm から $5 \mathrm{~mm}$ 間隔で 28 箇所において計測を行った.

図 8 に, フラットな底面に対して確率密度を用いて 求めた底面位置を示す，各プロットは，確率密度に対 するしきい值 $T h$ を $0.3 ， 0.5$ および 0.7 に設定した際 に決定された底面位置である．また，破線がスケール

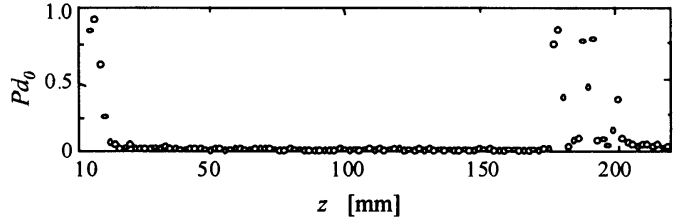

Fig. 7 Probability density of velocity in open channel

によって求められた実際の底面位置である. $T h=0.3$ の場合, 全ての点で実際の底面位置とよく一致してい る. 一方で $T h=0.5 ， 0.7$ としきい值が大きくなるに つれ，実際の底面位置よりも深く検出される場合が多 くなっている. この傾向はどの底面の場合でも共通し て見られ，本実験では全ての場合で $T h=0.3$ において 誤差が最小となった. 図 9 およひ図 10 にゴルフボール, 人工芝の底面に対する底面検出結果を示す．図中の各 プロットが検出位置，破線が実際の底面位置であり， エラーバーは速度分布計測における空間分解能を示し ている. ゴルフボールの場合，ボール頂部では検出さ れた底面と実際の底面がよく一致しているが，谷部で は大きく誤差が生じている. 本実験で使用したトラン スデューサでは，超音波ビームは約 5 度の広がり角で 水中を伝播し，ゴルフボール表面付近ではビーム径が 発射時の 2 倍の約 $20 \mathrm{~mm}$ となる. その結果，ビームは 実際の底面より先にボールの側面に反射し，流速はゼ ロと計測されるため, ボールの谷部では実際の底面と 誤差が生じる．より表面の凹凸が細かい人工芝の場合， ビーム径よりも細かな凹凸は検出されず，底面がフラ ットな場合と似た結果となった. スケールによって計 測した人工芝の平均表面位置と比較すると，その差は 流速分布計測における分解能程度である．以上の結果 から，計測した流速分布に基づいた底面検出法では， その空間分解能は使用する超音波のビーム径に依存す

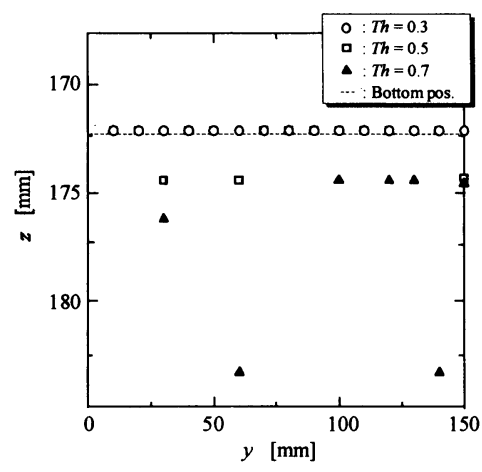

Fig. 8 Bottom of open channel determined by probability density method 


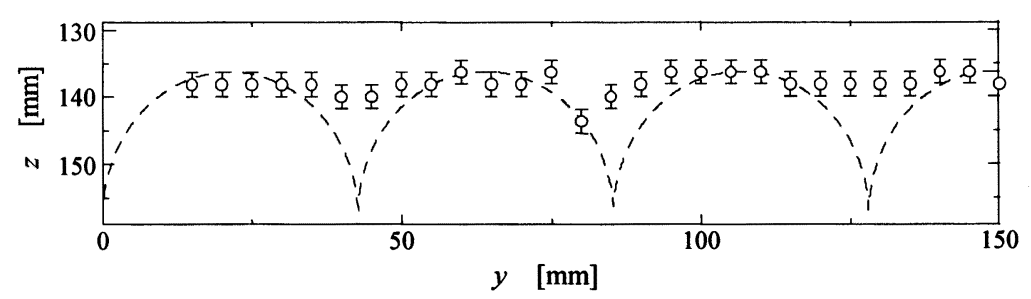

Fig. 9 Bottom of open channel paved with golf balls determined by probability density method

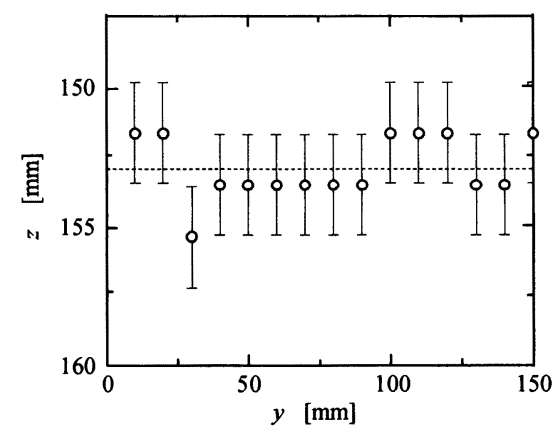

Fig. 10 Bottom of open channel paved with artificial grass determined by probability density method

るが, 従来行われてきたスケールによる計測と比較し て，十分な確度での底面検出が実現できることが分か った.

\section{6. 珢境流勤場計测}

6・1 計測対象および計睌条件 計測した川の概 略図を図 11 に示す.川は約 $50 \mathrm{~m}^{3}$ の池から流出して おり, 川幅 $1700 \mathrm{~mm}$, 平均水深約 $100 \mathrm{~mm}$ である. 計測部は流出部から約 $5 \mathrm{~m}$ の位置に設定した. 座標 軸は右岸水面を原点に取り, 図のように設定した。 $y=1000 \mathrm{~mm}$ 付近の上流側に岩が存在する. 底面は $y=0 \sim 1300 \mathrm{~mm}$ では粒径 $10 \mathrm{~mm}$ 程度の砂利であり, $y=1300 \sim 1700 \mathrm{~mm}$ では水草に覆われている. 計測 は $y=50 \sim 1650 \mathrm{~mm}$ まで $100 \mathrm{~mm}$ 毎に 17 個所で行 った. 流量の比較対照として川の流出部に四角堰を 設け, 越流水深を観測することにより流量を算出し た. UVPの計測パラメータは表 1 のとおりである.

$6 \cdot 2$ 計湜結果 計測結果の一例として, $y=350$ $\mathrm{mm}$ で計測された流速分布を図 12 に示す. 図 3 と同 様に, エラーバーは $u$ の標準偏差 $\sigma$ 示している.

図からわかるように, 実験室開水路での計測結果

(図 3）に比べて速度のばらつきが小さくなってお り, より高確度の流量計測が期待される. また, $\bar{u}$

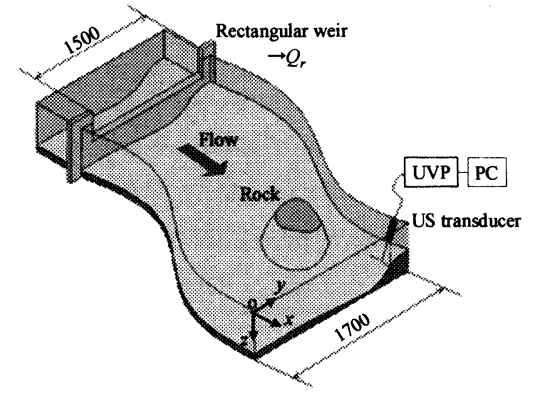

Fig. 11 Coordinates and measurement location at river

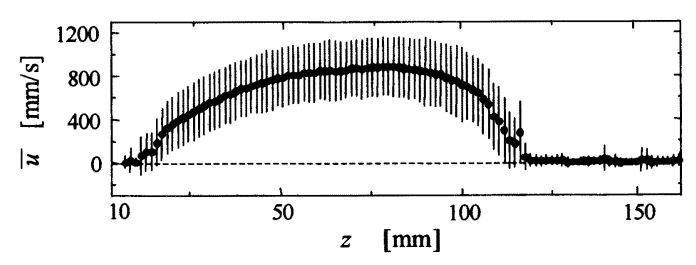

Fig. 12 Temporally averaged velocity profile in the river

がほぼぜロとなる底面近傍の点では標準偏差も小さ くなっており，実際の川の計測においても実験室水 路での底面検出方法をそのまま適用できる. なお実 験室開水路での計測と比較して, 瞬時速度分布には トレーサ不足の際に見られるデータの落ちがほとん ど存在しなかった.これは, 実際の川では気泡の他 に, 水中に浮遊する微細なちりなどがトレーサの役 割を果たしているためである.

実験室開水路での計測と同様に, 速度がゼロとな る確率を用いて底面検出を行った. 図 13 に, 確率 $P d$ に対するしきい值を 0.3 として底面位置の検出 を行った結果を, 平均流速の $y-z$ 断面分布とともに 示す. 図中の害線が流速データをもとに検出した底 面位置であり，破線は各計測位置においてスケール を用いて計測した底面位置である. カラースケール は, 速度の大きさを示している. 図から確認できる ように, $y=900 \mathrm{~mm}$ 付近に低速の領域が, またその 両側に比較的速度の大きい領域があり, 上流の岩が 


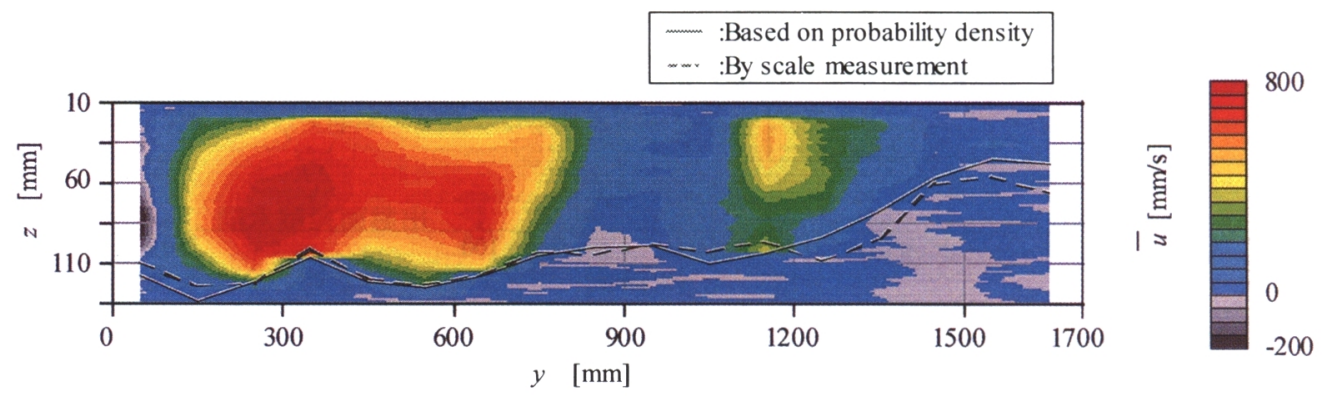

Fig. 13 Velocity distribution and detected bottom at $y-z$ section

形成する後流の影響が残っていることが分かる，底 面検出の結果では，底面が砂利である $y=1300 \mathrm{~mm}$ までは両者の差は平均約 $5 \mathrm{~mm}$ と, 砂利の粒径程度 である，一方，底面が水草で覆われている $y=1300$ $\mathrm{mm}$ 以降では, スケールによる計測結果と比較して $20 \mathrm{~mm}$ 程度浅く検出されている。このような誤差が 生じる原因を，流速分布の時間変動を用いて説明す る. 図 14 に, (a) $y=350 \mathrm{~mm}$ と(b) $y=1350 \mathrm{~mm}$ にお ける流速分布 $u(z)$ の時間変動を示す．図の横軸は時 間 $t$, 縦軸は $z$, またカラープロットによって $u$ の変 化を示している. $y=350 \mathrm{~mm}$ の場合は， $u=0$ となる $z$ 座標が $z=100 \mathrm{~mm}$ 付近でほぼ一定であることがわ かる。このような場合では底面の時間変動がなく, 精度の高い底面位置検出が可能である。これに対し て $y=1350 \mathrm{~mm}$ の場合は, $u=0$ となる $z$ 座標が一定 でなく変化している。これは流れにともなって，底 面を覆う水草が変動しているためである。 なお， ス ケールによる計測では水草表面までの正確な距離は 計測できないため，スケールに力を加えて静止する 位置を底面とした。一方，超音波は水草の表面で反 射されるため，水草が摇らいでいる場合には，スク 一ルによって計測した底面よりも浅い位置で速度が ゼロとなり，底面がより浅く検出される，スケール を目視で確認したところ，水草の高さは 10２0 mm であり，誤差と一致する．また水草の摇らぎにより， 底面近傍では速度が非常に遅く $u=0$ となる確率が 高くなっており，これも誤差を生じさせる要因とな っている。

$y-z$ 断面流速分布から前述の方法で補正を行い, 流量を算出した。なお, 河川では実験室水路と比較 して各計測線間での流速分布や断面形状の変化が大 きく，また実用化を考えてあえて $y$ 軸方向の計測間 隔を粗くしているため，断面流速分布に対して $y$ 方 向にスプライン補間を施した. その結果 $Q=53.1 \mathrm{l} / \mathrm{s}$ となり，堰によって計測された基準流量 $Q_{r}=55.0$

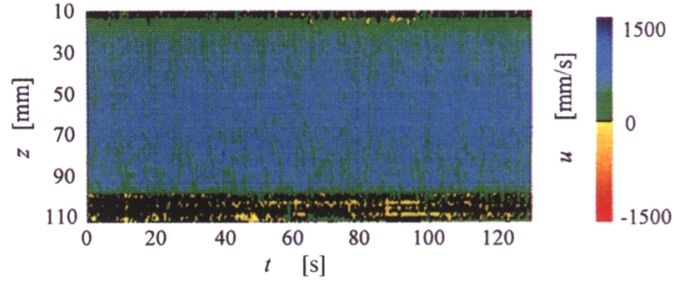

(a)

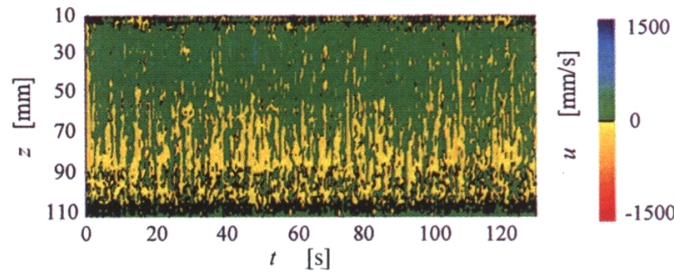

(b)

Fig. 14 Temporal-spatial velocity distribution; (a) gravel condition (at $y=350 \mathrm{~mm}$ ) and (b) waterweed condition (at $y=1350 \mathrm{~mm}$ )

1/s からのずれは約 4 \%となった。これは実験室水路 での流量計測確度と同程度であり，5～10\%程度の 誤差といわれる現行の河川流量計測確度 ${ }^{(3)}{ }^{(12)}$ を上 回るものである。

\section{7. 結 論}

本研究では，UVP を用いた環境流動場計測法の実 用化を目的として，開水路計測と実際の川での計測 を行った。得られた結論を以下に要約する.

（1）室内開水路において，流速分布をもとにいくつ かの補正を加えて流量を算出した．その結果，流れ を 1 次元流と仮定できるような，比較的乱れの小さ い場合には，誤差が $4 \%$ 程度の高確度流量計測が実 現できた。

(2) UVP によって計測した瞬時流速分布をもとに, 流速がゼロになる，流体力学的な底面を検出するこ 
とで，スケールを用いることなく底面を測定する方 法を提案した．開水路および川での検証実験の結果， 水草など底面位置が時間変動する場合を除き, 理想 的な平板や砂利など底面状態に関わらず，固定底面 では高精度での検出が可能であることを示した. た だし, ここで求められるのは UVP における測定体 積内の空間平均值としての底面である.

(3) 計測の効率化を図るため川幅方向の計測間隔を 粗くしたにもかかわらず，実際の川での流量計測誤 差は，四角堰を用いて計測した基準流量に対して約 4\%であうた。 これは現行の流量計測方法よりも高 確度である.

\section{文 献}

(1) Okada, T., et al., Proceedings of Hydraulic Engineering, Vol. 44 (2000), pp. 1227 - 1231.

(2) Yamaguchi , T. and Nizato, K., Proceedings of the Japan Society of Civil Engineers, No.497/II-28 (1994), pp. $41-50$.

(3) Kizawa, K. and Ide, Y., Proceedings of River engineering, Vol.7 (2001), pp.251 - 256 .
(4) Morlock, S.E., U.S. Geological Survey Water-Resources Investigations Report, (1996), pp. 37.

(5) Takeda, Y., JSME International Journal, B38 (1995), pp. $8-16$.

(6) Mori, M., et al., Experiments in Fluid, 32 (2002), pp. $153-160$.

(7) Mori, M., ELECTRICAL REVIEW, Vol.475 (2004), pp. $62-66$.

(8) Hersberger, D.S., Third International Symposium on Ultrasonic Doppler Methods for Fluid Mechanics and Fluid Engineering (2002), pp.59 - 66.

(9) O'Donoghue, T., Costal engineering, Vol.51 (2004), pp. 1163-1184.

(10) Wada, M., etal., Simpozium on the river engineering '03, Vol.19 (2003), pp. $231-234$.

(11) Ex., Taylor, J.R., An Introduction to Error Analysis, (2000), pp165-172.

(12) Kinoshita, T., Journal of Japan Rivers Association, 2004-1 (2004), pp.29-41. 